\title{
XX. Notices respecting new books
}

\section{Wronski}

To cite this article: M. Wronski (1821) XX. Notices respecting new books, Philosophical Magazine Series 1, 57:274, 135-138, DOI: 10.1080/14786442108652471

To link to this article: http://dx.doi.org/10.1080/14786442108652471

曲 Published online: 27 Jul 2009.

Submit your article to this journal $2 \pi$

Џ Article views: 2

Q View related articles $\asymp$ 
1820. h. $\mathrm{m}$.

Aug. 30 l O P.M. Ditto ditto with naked eye (about $37^{\circ}$ from $\odot$ ).

Sept. 31030 A.M. Ditto ditto, with 170, and ditto.

41230 P.M. Ditto ditto ditto.

7 during $\odot$ eclipse. Ditto rather brighter than at other times, with naked eye.

10915 A.M. Ditto very bright, through cirrhi, ditto.

111230 P.M. Ditto ditto on a clear sky, ditto.

121230 P.M. Ditto (appearances of inequalities with 170) ditto.

Oct. 19930 A.M. Ditto exceedingly bright, ditto.

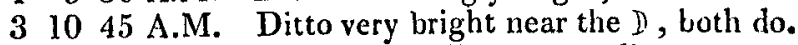

2811 0 A.M. Ditto ditto ditto.

Nov. 311 0 A.M. Ditto ditto ditto.

191130 A.M. Saw o again very bright in the telescope with 40 . difficult to find with naked eye (about $43^{\circ}$ from $\odot$ ).

Dec. 1220 P.M. Saw Jupiter near the $D$; also his belts in full sunshine with 40 ; middle bright belt much brighter than the rest of the planet, which was very pale, but pretty well defined; he was

1821. not so bright as the moon.

Jan. 16930 A.M. Saw 9 again in bright sunshine, invisible to the naked eye, very white, pale, and indistinct with 170 , but with 40 much better; alt. about $15^{\circ}$; she was visible through thin flying clouds.

Thus she was visible to the unassisted sight from a period anterior to 16th Mav, when I first saw her, until 15th June ; from that time, till about the 30th August, she was too near the sun to be seen without better eyes than mine, unless assisted by a telescope, when she again becama visible to the naked eye, and continued so until about the 19 th November : and, I may add, at various altitudes above $10^{\circ}$, below which, I am not certain I have seen her during sunshine.

XX. Notices respecting New Bookss.

M. Wronski and DR. Young.

To Mr. Tilloch.

Sir,-THe attention which has lately been paid in the Philosophical Magazine to astronomical subjects, entitles its Editor's opinion 
opinion of the Nautical Almanac to a certain degree of respect. He is therefore requested to state on what authority he has asserted, in the last Number, that "Dr. Young has pullicly acknowledged a blunder in his Postscript on Refraction, published in the Nautical Almanac for 1822."

London, Feb. 10, 1821.

The above request, though anonymous, is entitled to an answer, because the article alluded to (namely, the Notice respecting M. Wronski's Address to the Board of Longitude, which appeared in our last Number) was ineorrect. Dr. Young's acknowledgement was not publicly made, but was transmitted to $M$. Wronski in a private letter, in his capacity of secretary to a Public Board; and was published by the gentleman to whom it was addressed. Our mistake, we beg to say, was not intentional : the acknowledgement was before the public when we wrote the article alluded to ; aud, having beell made by Dr. Young, the fact for which we noticed it is no way affected by our inadvertency. Of this the public will judge from the following extract from M. Wronski's "Advice" prefixed to his Address :-

"Now, for reasons which will be learned in the present Address, the same [the Theory of Refractions] was returned to us, withont even undergoing an examination by the Board; as is proved by Dr. Young's letter, dated the 27th of April, which accompanied the reiurned Theory. Nevertheless, from the same proposition, some advantage resulted to the Board, who has declared to have perceived by it, that the New Table of Refractions which had just been produced in its Nautical Almanac for the year 1822, was false; as is proved by the letter of Dr. Young, dated the 18 th of April, at the time of the reception of the above theory, where, on acknowledging the same, he confesses immediately this error in the following terms :-

"I shall give no opinion of my own to the Board, except so far as to acknowledge that you have detected a blunder in my hasty Postscript on Refractions.

$$
\text { "، "Signed Thomas Young.," }
$$

Our article on M. Wronski's Address was originally of greater length than given in our pages. It concluded with an observation or two on a paragraph in his 96th page, "concerning new mathematical methods promised in the Nautical Almanac for 1822, as being to be inserted in the Philosoplical Transactions for $1819 \ldots \ldots$ from Dr. Young, Secretary of the Board of Longitude and of the Royal Society." This paper, which had "for its object astronomical refractions, and according to which has been calculated the Table of Refractions in the Nautical Almanac above cited," did not appear in the Philosophical Trans- 
actions, but was published separately under the title "Postscript to Dr. Young's Leller on the Reduction of Experiments ; No.5. Corrections for Refractions. These are the facts; and in cutting down the article in haste, to bring it within the limits of the page, the mistake occurred to which the foregoing letter of our correspondent alludes.

\section{Lately published.}

Observations on the Climate of Penzance and the District of the Land's End in Cornwall; with an Appendix, containing Meteorological Tables, and a Catalogue of the rarer indigenous Plants. By John Forbes, M.D. Secretary to the R.G.S.C. and Phrsician to the Penzance Dispensary. 8vo. pp. 70.

This work presents much useful matter condensed into a narrow compass. From the facts collected by the author, it appears evident that the temperature of Penzance is remarkable for its small annual, monthly, and daily range, and for its equability from day to day. The mean temperature of the winter there is so high as $42^{\circ}$, while that of summer does not exceed $57^{\circ}$ on an average of 14 years ; and the mean annual range is only $49^{\circ}$. The lowest degree to which the thermometer has fallen at Penzance during the last 14 years, has been $19^{\circ}$, and this only once.

A Series of Designs for Private Dwellings. By J. Hedgeland. Part 1. 4to. 1 $i$. 1s:

Specimens of Gothic Architecture selected from various Ancient Edifices in England. By A. Pugin, Architect. 4to. $1 \zeta .1 s$.

Practical Electricity and Galvanism ; containing a series of Experiments, calculated for the use of those who are desirous of becoming acquainted with that branch of science. By John Cuthbertson. 8vo. $12 s$.

General Elements of Pathology. By Whillock Nicholl, M. D. 8vo. $9 s$.

A Synopsis of the various Kinds of difficult Parturition, with Practical Remarks on the Management of Labours. By Samuel Merriman, M.D. 8vo. $12 s$.

Mathematical Essays. By the late W. Spence, Esq. 4to. 1l.16s.

Universal Science, or The Cabinet of Nature and Art. 2 Vols. 8vo. By Alexander Jamieson. $16 s$.

\section{Preparing for Pullication.}

Dr. Granville is preparing Memoirs on the present State of the Sciences in France, containing a description and historical account of the Royal Garden of Plants; the Royal Institute; the Polytechnic School; the Faculty of Sciences; and the Cabinet of Mineralogy; the Public Libraries ; the Medical School, and the Hospitals, \&ic.

Vol. 57. No.274. Fel. 1821. 
Journal of an $\mathrm{H}$ orticultural Tour in the Netherlands and North of France, in the Autumn of 1817. By P. Neill, J. Hay, and J. Macdonald, a Deputation of the Caledonian Horticultural Society.

The Substance of the late Professor Dalzell's Lectures on the Ancient Greeks, and on the Revival of Greek Learning, will soon be published by his son, John Dalzell, Esq. Advocate.

Illustrations of British Ornithology. By P. J. Selby, Esq. Elephant folio.

A Dissertation, showing the identity of the Rivers Niger and Nile; chiefly from the authority of the Ancients. By J. Dudley, M.A.

An Itinerary of the Rhone, ineluding part of the Southern Coast of France. By J. Hughes, Esq. A.M. of Oriel College, Oxford.

Manual of Mineralogy. By Prof. Jamieson of Edinburgh. Svo. Flora Scotica; or A Description of the Plants indigenous to Scotland and the Isles. By Prof. Hooker of Glasgow. I Vol. Svo.

A Practical Treatise on Diseases of the Heart. By Penry Reeder, M.D. Extraordinary Member of the Royal Medical Society of Edinburgh, and Meinber of the Medical and Chirurgical Society of London. In which is comprised a full account of all the diseases of that organ, as the Inflammatory, Organic, and Sympathetic, together with their appropriate modes of treatment ; also an account of Malconformations of the Heart, Aneurism of the Aorta, Pulsation in Epigastris, \&c.

J. B. Benwell intends shortly to publish an Essay on Interest Annuities, chiefly on deducing the values, when payable by instalments at intervals periodically fractional to yearly; as half yearly, quarterly, monthly : with Notes and Illustrations, and a brief Introduction on the study and practice of Life Assurance.

\section{Proceedings of Learned Socielies.}

ROYAL SOCIETY.

Jan. 18. INQUikies relative to the urinary organs and secretion of two species of Rana, common in Ceylon, by Dr. Davy, were read. From the statements of the author it appears, that the bladder of the bull-frog and brown toad (the two species in question) is a genuine receptacle for urine, which it receives from the cloaca in which the ureters terminate; and that their urine is not at all analogous to that of other animals of the order of amphibia, being very dilute, containing urea and certain salts, but no appreciable quantity of lithic acid. This is the more remarkable, as the favourite food of these animals is the sane as that of small lizards, whose urine is of a butyraceous consistence, and nearly 